Gut, 1977, 18, 615-622

\title{
Calcitonin and exocrine pancreatic secretion in man: inhibition of enzymes stimulated by CCK-pancreozymin, caerulein, or calcium-no response to vagal stimulation ${ }^{1,2}$
}

\author{
J. HOTZ, ${ }^{3}$ H. GOEBELL, AND R. ZIEGLER
}

From the Medical Clinic, Division of Gastroenterology, University of Essen, Essen, and from the Department of Internal Medicine, University of Ulm, Ulm, West-Germany

SUMMARY The effect of calcitonin on human pancreatic secretion was studied under various conditions of stimulation. During administration of both secretin plus cholecystokinin-pancreozymin (CCK-PZ) or secretin plus caerulein, enzyme secretion was promptly reduced by an infusion of calcitonin of more than $50 \%$. In contrast, vagally stimulated enzyme secretion induced by insulinhypoglycaemia or carbamyl-choline was not altered against a background infusion of calcitonin in comparison with control experiments. Calcium-induced enzyme secretion was abolished by additional calcitonin infusion which also prevented an increase in serum calcium. On the other hand, additional high grade calcium infusion did not modify the inhibitory action of calcitonin on enzyme output stimulated by secretin and CCK-PZ. Secretion of fluids and bicarbonate remained unaffected by calcitonin in all experimental conditions, whereas the outputs of calcium and magnesium paralleled generally the changes in enzymes. It is suggested that calcitonin interferes with hormonemediated stimulation of the acinar cells without influencing cholinergic mechanisms. The inhibitory action of calcitonin on enzyme secretion does not appear to be mediated by a depletion of extracellular calcium in the pancreatic tissue by calcitonin.

Calcitonin is known to inhibit human pancreatic enzyme secretion without affecting volume and bicarbonate output during stimulation with simultaneous intravenous infusions of secretin and cholecystokinin-pancreozymin (CCK-PZ) (Schmidt et al., 1971; Hotz et al., 1973). Though in these studies no relevant changes in serum calcium were seen, it has been suggested that this inhibitory effect of pharmacological doses of calcitonin could be related to an extracellular depletion of calcium in the pancreatic tissue. This possibility was discussed because, in man, acute lowering of serum calcium by infusion of EDTA led to a striking reduction in

\footnotetext{
1Presented in part at the 7th Meeting of the European Pancreatic Club, Dundee, UK, July 1974.

'Supported by the Deutsche Forschungsgemeinschaft, Grant Ho 500/1-3.

${ }^{3}$ Address for correspondence: Division of Gastroenterology, Medical Clinic, University of Essen, Hufelandstr. 55, D 4300 Essen 1, West-Germany.
}

Received for publication 24 December 1976 enzyme secretion stimulated by CCK-PZ, while acutely induced hypercalcaemia increased enzyme secretion during continuous infusion of secretin (Hotz et al., 1973; Goebell et al., 1973b).

In order to gain more information about the nature of the inhibitory action of calcitonin on the human pancreas, in the present study two major approaches were performed:

1. The effects of calcitonin on exocrine pancreatic secretion stimulated by CCK-PZ or by the decapeptide caerulein were compared with the effects when the organ was challenged by insulin hypoglycaemia, carbamylcholine, or calcium.

2. The effect of calcitonin was examined in the presence of additional calcium infusions, using varying doses of calcitonin and calcium.

\section{Methods}

Studies were made on 37 volunteers ( 28 men, nine women, between 22 and 48 years, average 29) who gave informed consent. 
EXPERIMENTAL DESIGN

After an overnight fast, a radio-opaque double lumen Lagerlöf tube was placed into the duodenum under $x$-ray control, the tip of the tube ending in the region of the ligament of Treitz. During the tests the subjects were lying on their backs. Gastric and duodenal juices were separately aspirated by continuous suction, using a negative pressure of about $20 \mathrm{~cm} \mathrm{H}_{2} \mathrm{O}$. In order to prevent obstruction of the lumina, some millilitres of air were insufflated by hand every three to five minutes into both openings of the tube. Duodenal samples were collected in ice-cooled flasks in 15- and 20-minute intervals for determination of volume, bicarbonate, trypsin, chymotrypsin, amylase, calcium, and magnesium; the gastric juice was discarded. Serum calcium levels were controlled periodically throughout the experiments.

Altogether four different types of experiments were carried out, dividing the total of 37 test persons into four major groups (Table 1).

1. In group Ia $(n=5)$ pure natural secretin ${ }^{4}$ (1 clinical unit (CU) per $\mathrm{kg}$ body weight per hour) and CCK-PZ ${ }^{4}$ (1 Crick-Ivy-Harper unit (U) per kg per hour) were given by a constant intravenous infusion for a total of 150 minutes. From the beginning of the second hour until the end of the experiment, synthetic salmon calcitonin ${ }^{5}$ was additionally infused, using a dose of 60 Medical Research Council units (MRC-U) per subject per hour.

'GIH Research Unit, Karolinska Institute, Stockholm, Sweden.

${ }^{5}$ Kindly supplied by Dr A. Petrin, Sandoz Company, Basel, Switzerland.
This dose of synthetic salmon calcitonin was chosen after having shown elsewhere that it causes maximal inhibition of enzyme secretion stimulated by secretin and CCK-PZ (Hotz et al., 1973). It can be assumed that these doses are pharmacological and induce serum calcitonin levels above the physiological range. However, since the biological activity of synthetic salmon calcitonin is 30 - to 40 -fold that of human calcitonin, an exact comparison with endogenous physiological concentrations is impossible.

In group $\mathrm{Ib}(\mathrm{n}=5)$ the same dose schedule was applied but synthetic decapeptide caerulein ${ }^{6}$ was used ( $75 \mathrm{mg}$ per $\mathrm{kg}$ body weight an hour) instead of CCK-PZ.

2. In group IIa $(n=4)$ secretin $(0.25 \mathrm{CU} / \mathrm{kg}$ per h) and synthetic salmon calcitonin (60 MRC U/h) were infused throughout the experiment lasting 210 minutes. Sixty minutes from the beginning, insulin ( $0.2 \mathrm{IU}$ per $\mathrm{kg}$ body weight, Altinsulin $\left.{ }^{7}\right)$ was given by single intravenous injection. In these experiments blood sugar values were measured in 30minute intervals by routine methods.

In group IIb $(n=4)$ the same dose schedule was applied but carbamylcholine was administered subcutaneously $\left(0.25 \mathrm{mg}\right.$ per subject, Doryl $\left.{ }^{8}\right)$ instead of insulin.

3. In group III $(n=4)$ secretin $(0.5 \mathrm{CU} / \mathrm{kg} . \mathrm{h})$ was infused together with synthetic salmon calcitonin (40 MRC U/h) for the entire test period of 120 minutes. A constant intravenous infusion of calcium-gluco-lactobionate was superimposed 30

${ }^{6}$ Farmitalia, Milan, Italy.

${ }^{7}$ Hoechst, Frankfurt/M, West-Germany.

${ }^{8}$ Merck, Darmstadt, West-Germany.

Table 1 Experimental design of different tests

\begin{tabular}{|c|c|c|c|c|c|c|c|}
\hline Group & $n$ & Background stimulation & $\begin{array}{l}\text { Duration } \\
\text { (min) }\end{array}$ & $\begin{array}{l}\text { Modification of } \\
\text { calcium-homeostasis }\end{array}$ & $\begin{array}{l}\text { Duration } \\
\text { (min) }\end{array}$ & $\begin{array}{l}\text { Vagal } \\
\text { stimulation }\end{array}$ & $\begin{array}{l}A t \\
(\min )\end{array}$ \\
\hline Ia & 5 & $\begin{aligned} & \text { Sk (1 CU/kg.h) } \\
+ & \text { CCK-PZ (1 U/kg.h) }\end{aligned}$ & $0-150$ & S-CT $(60 \mathrm{MRCU} / \mathrm{h})$ & $60-150$ & \multirow{9}{*}{$\begin{array}{l}\text { Insulin } \\
(0 \cdot 2 \mathrm{IU} / \mathrm{kg}) \\
\text { Carbamylcholine } \\
(0 \cdot 25 \mathrm{mg})\end{array}$} & \multirow{9}{*}{60} \\
\hline Ib & 5 & $\begin{aligned} & \text { Sk (1 CU/kg.h) } \\
+ & \text { Caer. (75 /g/kg.h) }\end{aligned}$ & $0-150$ & S-CT (60 MRCU/h) & $60-150$ & & \\
\hline IIa & 4 & Sk (0.25 CU/kg.h) & $0-210$ & S-CT (60 MRCU/h) & $0-210$ & & \\
\hline IIb & 4 & Sk (0.25 CU/kg.h) & $0-210$ & S-CT (60 MRCU/h) & $0-210$ & & \\
\hline III & 4 & Sk (0.5 CU/kg.h) & $0-210$ & $\begin{array}{l}\text { S-CT (40 MRCU/h) } \\
\mathrm{Ca}^{++}(0 \cdot 25 \mathrm{mM} / \mathrm{kg} \cdot \mathrm{h})\end{array}$ & $\begin{array}{r}0-120 \\
30-120\end{array}$ & & \\
\hline IVa & 7 & $\begin{aligned} & \text { Sk (1 CU/kg.h) } \\
+ & \text { CCK-PZ (1 U/kg.h })\end{aligned}$ & $0-120$ & $\begin{array}{l}\mathrm{Ca}^{++}(0.063 \mathrm{mM} / \mathrm{kg} \cdot \mathrm{h}) \\
\mathrm{P}-\mathrm{CT}(50 \mathrm{MRCU})\end{array}$ & $\begin{array}{l}40-100 \\
60-90\end{array}$ & & \\
\hline IVb & 4 & $\begin{aligned} & \text { Sk (1 CU/kg.h) } \\
+ & \text { CCK-PZ (1 U/kg.h) }\end{aligned}$ & $0-120$ & $\begin{array}{l}\mathrm{Ca}^{++}(0.063 \mathrm{mM} / \mathrm{kg} \cdot \mathrm{h}) \\
\mathrm{P}-\mathrm{CT}(15 \mathrm{MRCU})\end{array}$ & $\begin{array}{l}40-100 \\
60-90\end{array}$ & & \\
\hline & 4 & $\begin{aligned} & \text { Sk (1 CU/kg.h) } \\
+ & \text { CCK-PZ (1 U/kg.h) }\end{aligned}$ & $0-120$ & $\begin{array}{l}\mathrm{Ca} a^{++}(0.25 \mathrm{mM} / \mathrm{kg} . \mathrm{h}) \\
\text { P-CT (15 MRCU) }\end{array}$ & $\begin{array}{l}40-100 \\
60-90\end{array}$ & & \\
\hline Contr & & and III: saline in place & & n saline. & & & \\
\hline
\end{tabular}

All doses were intravenous with the exception of carbamylcholine, which was subcutaneously administered.

Salmon (S-CT)- or porcine (P-CT) calcitonin were infused in the presence of different modes of background stimulation (secretin = Sk. cholecystokinin-pancreozymin $=$ CCK-PZ, caerulein $=$ caer., insulin hypoglycaemia, carbamylcholine or calcium). 
minutes after the beginning of the test, using a dose of $0.25 \mathrm{mmol}$ calcium ions per $\mathrm{kg}$ body weight an hour (Calcium-Sandoz ${ }^{9}$.

4. In group IV pancreatic secretion was stimulated by a constant infusion of secretin and CCK-PZ ( $1 \mathrm{CU} / \mathrm{kg}$ per $\mathrm{h}$, intravenously, each hormone) throughout the test period of 120 minutes. Forty minutes after beginning the test, a calcium infusion was added for one hour, and, 20 minutes after starting the calcium infusion, an additional infusion of purified porcine calcitonin ${ }^{10}$ was superimposed for 30 minutes, using different doses of calcium and purified porcine calcitonin in three different test series.

Group IVa $(\mathrm{n}=7)$ received $0.063 \mathrm{mmol} \mathrm{Ca}^{++}$ per $\mathrm{kg}$ body weight an hour together with $50 \mathrm{MRC}$ $\mathrm{U}$ purified porcine calcitonin per subject and 30 minutes, group IVb $(n=4)$ correspondingly 0.063 $\mathrm{mmol} \mathrm{Ca}{ }^{++}$per $\mathrm{kg}$ an hour and $15 \mathrm{MRC} \mathrm{U}$ per 30 minutes purified porcine calcitonin, while in group IVc $(\mathrm{n}=4) 0.25 \mathrm{mmol} \mathrm{Ca} \mathrm{C}^{++}$per $\mathrm{kg}$ an hour were combined with 15 MRC $U$ per 30 minutes purified porcine calcitonin.

\section{CONTROL STUDIES}

All hormones and calcium salts were dissolved in saline (100 $\mathrm{ml}$ per hour). In groups I, II, and III, control studies were performed in the same subjects on separate days, using saline alone in place of calcitonin dissolved in saline. The sequences of the test and control studies were randomly alternated.

\section{ANALYTICAL METHODS}

Volumes of all duodenal samples were measured in millilitres, and aliquots centrifuged at $4^{\circ} \mathrm{C}$ at $5000 \mathrm{~g}$ for 15 minutes (Sorvall RC-2). The bicarbonate concentration of the supernatant was analysed in $1 \mathrm{ml}$ samples by adding $2 \mathrm{ml} 0.01 \mathrm{M} \mathrm{HCl}$ and backtitrating with $0.01 \mathrm{M} \mathrm{NaOH}$ to $\mathrm{pH} 7.0$ after boiling (Titrigraph, Herisau, Switzerland).

All enzyme measurements were made after storage at $4^{\circ} \mathrm{C}$ less than four hours thereafter. Activities of trypsin were determined in a Beckman spectrophotometer, using benzoyl-arginine-ethylester (BAEE) (Schwert and Takenaka, 1955), and those of chymotrypsin, using toluol-argininemethyl-ester (TAME) (Hummel, 1955). Activities of amylase were estimated using starch-buffer solution and dinitrosalicylic acid according to Bernfeld (1955). All enzyme determinations were made at $25^{\circ} \mathrm{C}$. BAEE and TAME were purchased from Serva Laboratories, Heidelberg, West-Germany, and all

\footnotetext{
9Sandoz Company, Nürnberg, West-Germany.

${ }^{10}$ Kindly supplied by Dr J. W. Bastian, Armour Pharmaceutical Co. Ltd., Kankakee, Ill. (USA).
}

other chemicals from Merck, Darmstadt, WestGermany.

In duodenal juice as well as in peripheral serum samples, concentrations of calcium and magnesium were analysed by atomic absorption spectrophotometry.

Statistical significance was evaluated by application of Student's $t$ test for paired samples (Olivetti computer $\mathbf{P}$ 101). The zero hypothesis was rejected at the $5 \%$ level.

\section{Results}

EFFECTS OF CALCITONIN UNDER HORMONAL STIMULATION (CCK-PZ, CAERULEIN)

Figure 1 illustrates the effect of a continuous infusion of salmon calcitonin in a dose of $60 \mathrm{MRC}-U$ per hour on the secretion of trypsin as stimulated by background infusions either of secretin plus CCKPZ (group Ia) or of secretin plus caerulein (group Ib), respectively. Under both stimulatory conditions, salmon calcitonin infusion was accompanied by a prompt reduction in trypsin secretion by about $50 \%$ in comparison with both the output in the first hour without calcitonin as well as with the control values obtained on another day, the latter remaining unchanged during the entire test period of 150 minutes.

Serum calcium and magnesium values did not alter during any of the conditions.

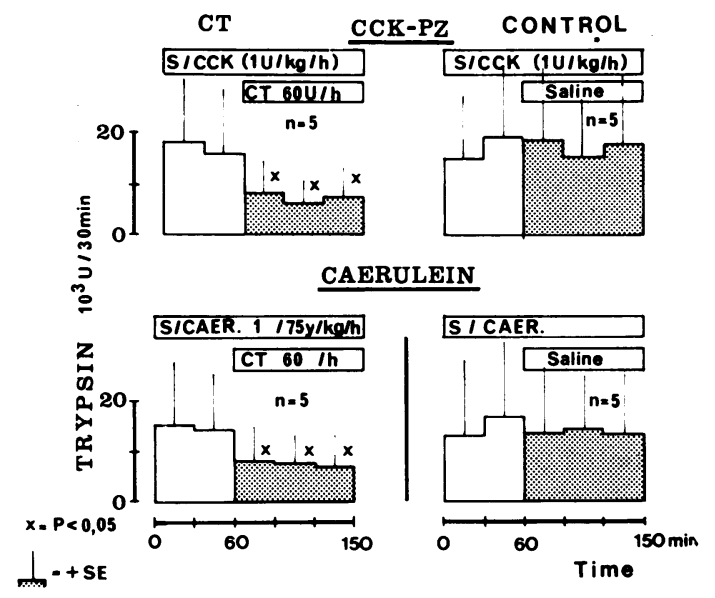

Fig. 1 Effect of synthetic salmon calcitonin ( $C T$, $60 M R C-U$ per hour) on human trypsin secretion stimulated by continuous intravenous infusion of secretin $(S)$ and cholecystokinin-pancreozymin $(C C K-P Z$, $1 \mathrm{U} / \mathrm{kg}$ per $\mathrm{h}$, each hormone) (group Ia, left above) or of secretin (1 U/kg per $h$ ) and caerulein $(75 \mu \mathrm{g} / \mathrm{kg} \mathrm{per}$ h) (group Ib, left below) in comparison with the control values obtained in the same subject using saline in place of calcitonin dissolved in saline (right above and below) $(n=5)$. 
Table 2 Effects of infusion of $60 \mathrm{MRC}-U$ of synthetic salmon calcitonin per hour on duodenal volumes, bicarbonate, chymotrypsin, amylase, calcium, and magnesium under continuous stimulation with secretin (I U/kg per h) and caerulein $(75 \mu g / k g$ per $h)$ compared with control values under secretin and caerulein without calcitonin (group Ib)

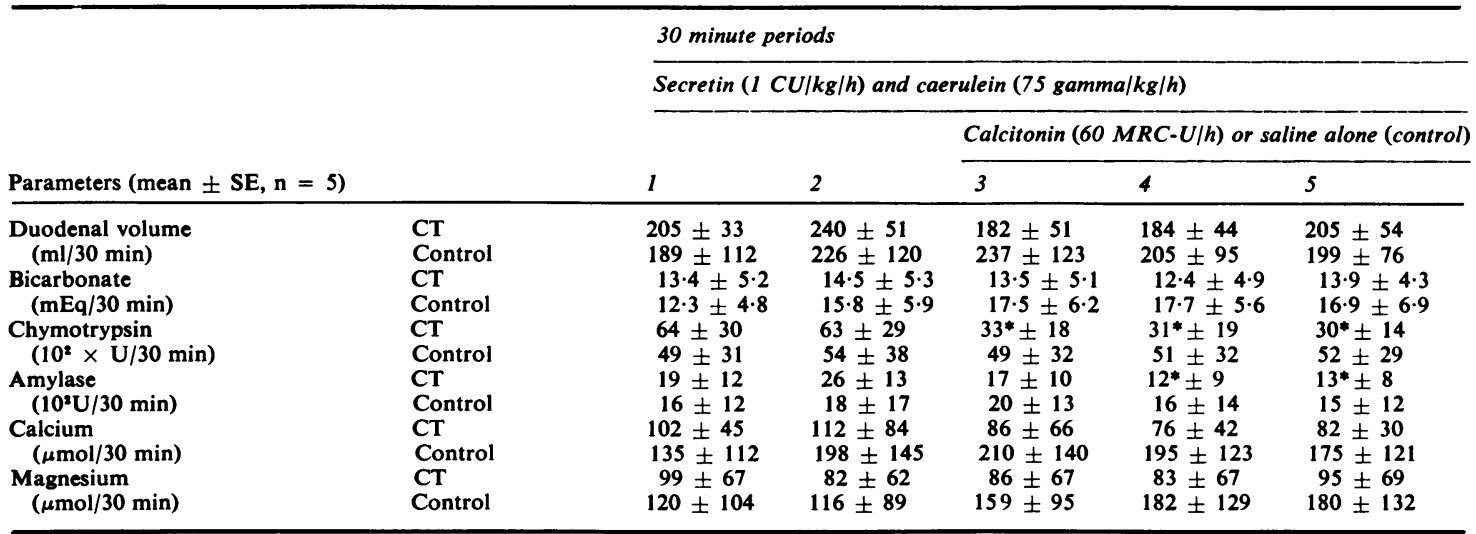

*Statistically significant versus control $(\mathrm{P}<0.05)$.

In Table 2, the effects of salmon calcitonin on the different secretory values measured in the duodenal juice under stimulation with secretin and caerulein are summarised. These values were not significantly different from those obtained under stimulation with secretin plus CCK-PZ.

Chymotrypsin and amylase activities showed a pattern similar to trypsin-that is, reduction of more than $50 \%$ in response to salmon calcitonin. In terms of volumes and bicarbonate, no change was observed under salmon calcitonin. The output of magnesium did not alter under these conditions. The decrease of less than $30 \%$ in the duodenal content of calcium during salmon calcitonin was not statistically significant.

EFFECTS OF CALCITONIN UNDER VAGAL STIMULATION (INSULIN, CARBAMYLCHOLINE) Figure 2 illustrates the effects both of a single intravenous injection of $\mathbf{0 . 2} \mathrm{IU}$ per $\mathrm{kg}$ body weight of insulin (group IIa) and of a single subcutaneous injection of $0.25 \mathrm{mg}$ carbamylcholine (group IIb) on trypsin secretion during constant background infusions of secretin and salmon calcitonin in comparison with the effects during secretin alone.

After injection of insulin, blood sugar reached values below $40 \mathrm{mg} / 100 \mathrm{ml}$ in each case. This was accompanied by a four- to fivefold increase in trypsin secretion in the second 30 -minute period after insulin followed by a gradual fall in the subsequent periods, not only under test conditions using calcitonin, but also in the control studies. Similarly, there were no significant differences in trypsin responses to carbamylcholine in the calcitonin treated state, as compared with controls. Under

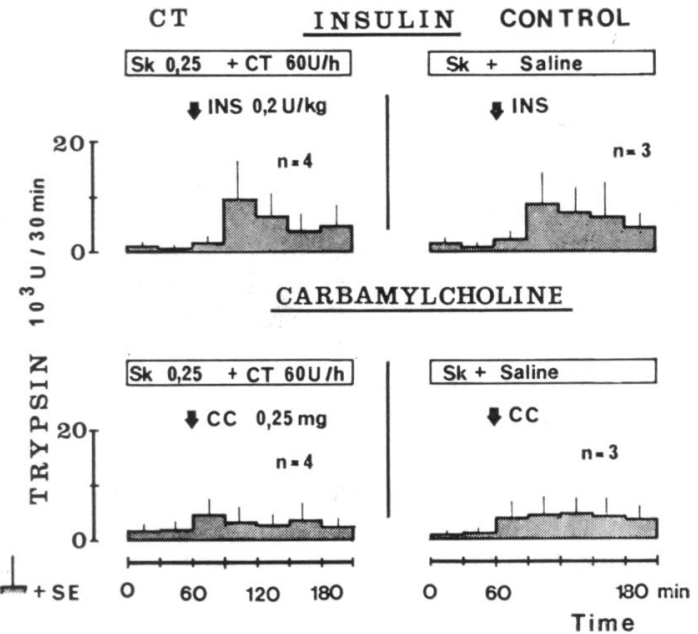

Fig. 2 Effect of synthetic salmon calcitonin (CT) on vagally stimulated human trypsin secretion (group II a and IIb): the enzyme response during background infusion of calcitonin (60 MRC-U/h) plus secretin $(S, 0.25 \mathrm{U} / \mathrm{kg}$ per $\mathrm{h})(\mathrm{left})$ did not differ significantly from the control values obtained without calcitonin (right), either after insulin hypoglycaemia (above), or after carbamylcholine (below).

both control and test conditions, the increase in trypsin secretion was less pronounced after carbamylcholine than after insulin.

In Table 3, details of the duodenal parameters are given. The output of chymotrypsin and amylase paralleled those of trypsin secretion in all experiments. Increases in volumes and bicarbonate output were much more pronounced after insulin than after 
Table 3 Responses of duodenal volumes, bicarbonate, chymotrypsin, amylase, calcium and magnesium to an injection of insulin (I) or carbamylcholine $(C C)$ under continuous infusion of secretin plus synthetic salmon calcitonin $\left(I_{\mathrm{CT}}=\right.$ group Ila, CC $\mathrm{CT}=g r o u p$ IIb) $\dagger$

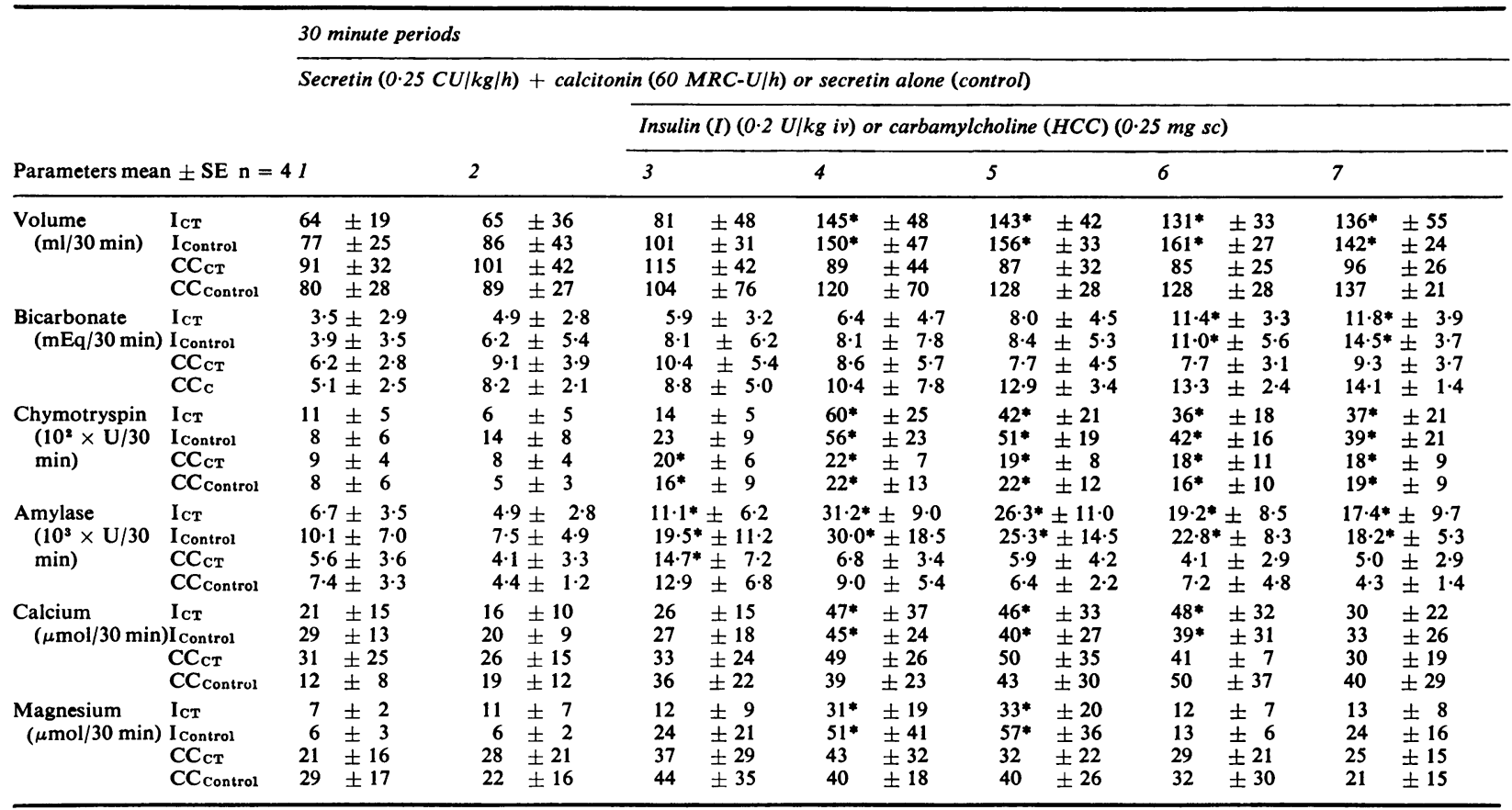

*Significant versus period 2 ( $P<0.05$, paired samples).

$\dagger$ These values are compared with control data obtained under continuous infusion of secretin alone ( $\mathrm{I}_{\text {control }}$ and $\left.\mathrm{CC}_{\mathrm{control}}\right)$.

carbamylcholine, but this was found during infusion of calcitonin as well as in the control tests.

The maximal increases in calcium and magnesium secretion amounted to about 200 to $300 \%$ of the inital values in response to both stimulants during calcitonin as well as in the controls.

\section{EFFECTS OF CALCITONIN UNDER}

STIMULATION WITH CALCIUM

The intravenous infusion of calcium $(0.375 \mathrm{mmol} /$ $\mathrm{kg}$ per $90 \mathrm{~min}$ ) resulted in an increase in serum calcium of about $1 \mathrm{mmol} / \mathrm{l}$ during secretin infusion alone. Hypercalcaemia induced a peak secretion of trypsin, chymotrypsin, and amylase of about 250 to $400 \%$, as compared with the initial range before calcium. In contrast, in the presence of constant infusion of calcitonin, neither serum calcium nor enzyme secretion responded to the superimposed calcium infusion of the same dose (group III) (Fig. 3 ). Volumes and bicarbonate remained unaffected by calcium infusion with or without calcitonin, and they did not differ significantly, as compared in test and control studies. haviour similar to enzyme output : under control conditions, calcium infusion brought about maximal increases in total calcium output from $15 \pm 11 \mu \mathrm{mol} /$ $15 \mathrm{~min}$ to $54 \pm 37$, and for magnesium from $19 \pm$ $5 \mu \mathrm{mol} / 15 \mathrm{~min}$ to $40 \pm 24$, whereas only slight and non-significant increases were observed in the presence of the calcitonin background infusion-that is, calcium from $10 \pm 6$ to $17 \pm 12$, and magnesium from $6 \pm 3$ to $15 \pm 9 \mu \mathrm{mol} / 15 \mathrm{~min}$. These changes in total outputs were exclusively caused by increases in concentrations.

\section{EFFECTS OF CALCITONIN ON HORMONAL STIMULATION UNDER SIMULTANEOUS}

\section{CALCIUM INFUSION}

The calcitonin-induced reduction in enzyme secretion, stimulated by constant infusion of secretin and CCK-PZ was not altered in the presence of simultaneous calcium infusion. This was observed under all the different dose schedules used: against low grade calcium infusion $(0.063 \mathrm{mmol} / \mathrm{kg}$ per h) the mean maximal decrease in trypsin secretion in response to $50 \mathrm{MRC}-\mathrm{U}$ per $30 \mathrm{~min}$ of porcine calcitonin (group IVa), as well as to $15 \mathrm{MRC}-\mathrm{U}$ per 30 


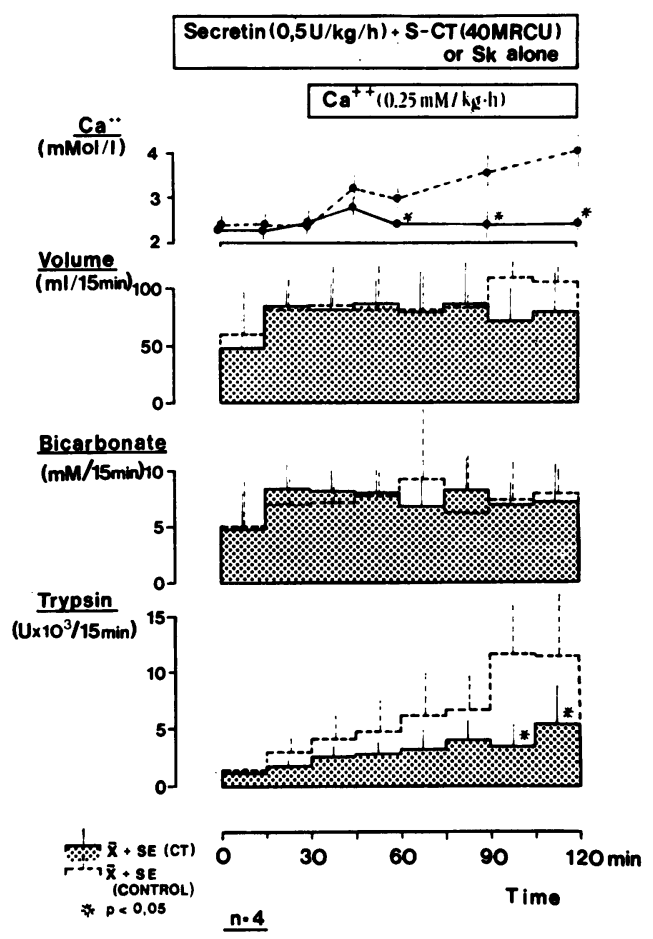

Fig. 3 Effect of calcium infusion $(0.375 \mathrm{mmol} / 90$ min) on serum calcium and pancreatic secretion in four normal subjects in the presence of simultaneous infusions of secretin plus synthetic salmon calcitonin $(S-C T$, $40 \mathrm{MRC}-U / h$, group III) or secretin alone without $S-C T(S k, 0.5 \mathrm{U} / \mathrm{kg}$ per $h$, controls) values of pancreatic secretion: volumes, bicarbonate, and trypsin content of duodenal juice samples. In contrast with the controls showing an increase in enzyme secretion after calcium, there were no increases in serum calcium as well as in enzymes in the $S$-CT-treated state $(n=4)$.

min of porcine calcitonin (group IVb), amounted to $62 \%$ and $54 \%$, respectively, the serum calcium showing only a slight increase of less than 0.5 $\mathrm{mmol} / \mathrm{l}$. When the low grade infusion of $15 \mathrm{MRC}-\mathrm{U}$ of porcine calcitonin over 30 minutes was given against a high grade calcium infusion of $0.25 \mathrm{mmol}$ per $\mathrm{kg}$ an hour (group IVc), the decrease in trypsin output was $69 \%$, though in these studies the average serum calcium level rose by more than $1 \mathrm{mmol} / \mathrm{l}$ (Fig. 4).

Amylase paralleled trypsin, whereas fluid and bicarbonate outputs were not found to be altered under different conditions. Secretion of calcium and magnesium corresponded significantly to enzyme values in these studies and did not show dependence on the differently graded infusions of calcium and calcitonin.

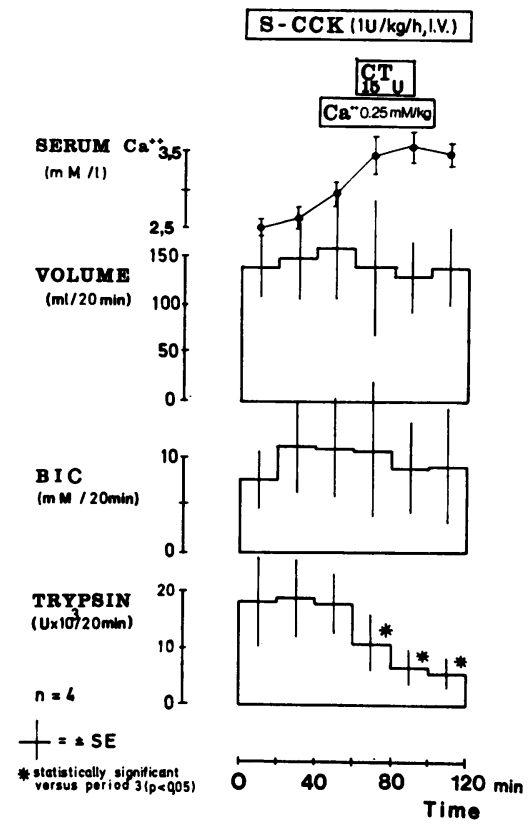

Fig. 4 Effect of a low dose infusion of porcine calcitonin (CT, $15 \mathrm{MRC}-\mathrm{U} / 30 \mathrm{~min})$ during simultaneous administration of a high dose infusion of calcium $(0.25 \mathrm{mmol} / \mathrm{kg}$ per $h)$ on serum calcium and pancreatic secretion stimulated continuously by secretin and cholecystokinin-pancreozymin (S-CCK, I U/kg per h, each hormone) (group IVc, $n=4)$. Values: volumes, bicarbonate and trypsin content of duodenal juice samples.

\section{Discussion}

\section{ENZYME SECRETION}

The results presented here confirm previous reports that intravenous infusion of calcitonin causes a distinct reduction of human pancreatic enzyme secretion stimulated by CCK-PZ (Schmidt et al., 1971; Hotz et al., 1973). In addition, a similar degree of inhibition was found when the pancreas was stimulated by the analogue decapeptide caerulein. In contrast, no inhibitory effect of calcitonin on vagally stimulated enzyme secretion could be shown when evoked by insulin-mediated hypoglycaemia or by the cholinergic drug carbamylcholine.

Both types of vagal excitation are supposed to be mediated by different pathways: insulin possibly via atropine-resistant vagal fibres (Wolfert et al., 1974), and carbamylcholine via atropine-sensitive cholinergic mechanisms (Hickson, 1970). It may be concluded from the present results that, in man, calcitonin does not interfere with either vagal stimulatory mechanisms.

The calcium-induced hypersecretion of enzymes 
against a background infusion of secretin appeared to be completely abolished by simultaneous infusion of calcitonin. But from these studies it cannot be decided whether this was the result of the simultaneous prevention of acute hypercalcaemia by calcitonin or of the direct interaction of acute hypercalcaemia on the secretory cells, or both. The hypothesis of a direct interaction is supported by observations from Becker et al. (1973) who found an inhibition of calcium-induced gastric secretion by calcitonin in the cat, a species in which the raised serum calcium remains unaffected by calcitonin.

The possibility that calcitonin acts on the acinar cell via local diminuation of the extracellular calcium pool seems improbable in the light of the present data; even a high grade calcium infusion, though itself stimulating enzyme secretion, did not modify the calcitonin-induced suppression of enzyme output. However, this does not exclude a possible influence of calcitonin on intracellular calcium storages, which are thought to be relevant for triggering enzyme secretion within the acinar cell (Case, 1973).

\section{FLUID AND BICARBONATE}

In general, fluid and bicarbonate secretion remained unaffected in all experimental conditions. In the caerulein experiments the mean values of bicarbonate secretion were not reduced in response to the infusion of calcitonin during the test, but they were distinctly lower than corresponding control values obtained in the same subjects on a separate day. Similarly, in the carbamylcholine experiments in the periods 5,6 , and 7 , bicarbonate outputs were reduced compared with corresponding control values. But these differences were not statistically significant, and might be the result of the considerable scattering of the secretory values from one test to another in one subject rather than a reflection of real inhibition of bicarbonate secretion by calcitonin.

In the presence of a constant infusion of secretin, using a submaximal dose of 0.25 clinical units per $\mathrm{kg}$ an hour, the relatively small output of fluids and bicarbonate increased in response to insulin hypoglycaemia, but not to carbamylcholine. Since insulinmediated pancreatic stimulation without secretin does not significantly influence hydrokinetic function in man (Lagerlöf and Welin, 1937), the present data suggest a potentiating effect of insulin hypoglycaemia on secretin. This is in agreement with previous findings of Brown et al. (1967) who observed a potentiation of submaximal doses of secretin by electrical stimulation of the vagus in the anaesthetised cat.

DUODENAL CALCIUM AND MAGNESIUM Calcium has been shown to be secreted in close rela- tion to enzyme proteins after stimulation with CCKPZ or calcium in man (Goebell et al., 1973a). A positive correlation between calcium and enzyme content in the duodenal juice was observed under all conditions used in the present investigations both in the test and control studies. Thus, it can be concluded that calcitonin as well as induced hypercalcaemia influences the secretion of calcium by the pancreas mainly because of their effects on enzyme secretion. However, an additional possible alteration of relatively small enzyme-independent calcium secretion (Goebell et al., 1973a) could be masked by the higher enzyme-associated calcium portion in the juice.

The excretion mechanism of magnesium into the pancreatic juice is not yet clear. Parallel excretion of calcium and magnesium was previously described in normal subjects and pancreatic insufficiency in response to secretin and CCK-PZ (Baltzer et al., 1974). The present observation that changes in magnesium output in each case resembled but did not strictly parallel changes in calcium excretion suggest that there are probably different secretory sites for both divalent cations in the human pancreas, as has been assumed also from experiments on dogs (Nakajima, 1973).

Thanks are due to Ms L. Cherian for skilful technical assistance.

\section{References}

Baltzer, G., Goebell, H., and Müller-Reinhardt, B. (1974). Magnesium und Calcium im Duodenalsaft bei verschiedenen Funktionszuständen des Pankreas und bei primärem Hyperparathyreoidismus. Klinische Wochenschrift, 52, 74-79.

Becker, H. D., Konturek, S. J., Reeder, D. D., and Thompson, J. C. (1973). Effect of calcium and calcitonin on gastrin and gastric secretion in cats. American Journal of Physiology, 225, 277-280.

Bernfeld, P. (1955). Alpha-amylase. In Methods in Enzymology, p. 149. vol. I. Edited by S. P. Colowick and N. O. Kaplan. Academic Press: New York.

Brown, J. C., Harper, A. A., and Scratcherd, T. (1967). Potentiation of secretion stimulation of the pancreas. Journal of Physiology, 190, 519-530.

Case, R. M. (1973). Cellular mechanism controlling pancreatic exocrine secretion. Acta Hepato-Gastroenterologica, 20, 435-444.

Goebell, H., Baltzer, G., Schlott, K. A., and Bode, Ch. (1973a). Parallel secretion of calcium and enzymes by the human pancreas. Digestion, 8, 336-346.

Goebell, H., Steffen, Ch., Baltzer, G., and Bode, Ch. (1973b). Stimulation of pancreatic secretion of enzymes by acute hypercalcaemia in man. European Journal of Clinical Investigation, 3, 98-104.

Hickson, J. C. D. (1970). The secretory and vascular response to nervous and hormonal stimulation in the pancreas of the pig. Journal of Physiology, 206, 299-322. 
Hotz, J., Minne, H., and Ziegler, R. (1973). The influences of acute hyper- and hypocalcemia and of calcitonin on exocrine pancreatic function in man. Research in Experimental Medicine, 160, 152-165.

Hummel, B. D. (1955). A modified spectrophotometric determination of chymotrypsin, trypsin and thrombin. Canadian Journal of Biochemistry, 33, 1339-1397.

Lagerlöf, H., and Welin, G. (1937). Pancreatic secretion after secretin during insulin hypoglycemia and after graded amounts of secretin. Acta Medica Scandinavica, 91, 397-408.

Marchis-Mouren, G., Sarda, L., and Desnuelle, P. (1959). Purification of hog pancreatic lipase. Archives of Biochemistry, 83, 309-319.
Nakajima, S. (1973). The action of C-terminal octapeptide of cholecystokinin and related peptides on pancreatic exocrine secretion. Gut, 14, 607-615.

Schmidt, H., Hesch, R. D., Hüfner, M., Paschen, K., and Creutzfeldt, W. (1971). Hemmung der exokrinen Pankreassekretion des Menschen durch Calcitonin. Deutsche medizinische Wochenschrift, 96, 1773-1775.

Schwert, G. W., and Takenaka, Y. (1955). Spectrophotometric determination of trypsin and chymotrypsin. Biochimica et Biophysica Acta, 16, 570-575.

Wolfert, W., Hartmann, W., and Hotz, J. (1974). Exocrine pancreatic secretion and output of bile in humans under conditions of hypoglycemia and administration of atropine. Digestion, 10, 9-16.

\section{The July 1977 Issue}

\section{THE JULY 1977 ISSUE CONTAINS THE FOLLOWING PAPERS}

Effects of proximal gastric vagotomy (PGV) followed by total vagotomy (TV) on postprandial and fasting myoelectrical activity of the canine stomach and duodenum P. AEBERHARD AND B. S. BEDI

Clinical picture of peptic ulceration diagnosed endoscopically M. C. SHEPPARD, G. K. T. HOLMES, AND R. COCKEL

Double-blind trial of cholestyramine in post-vagotomy diarrhoea V. M. DUNCOMBE, T. D. BOLIN, AND A. E. DAVIS

Correlation between manometric and $\mathrm{pH}$ tests for gastro-oesophageal reflux C. STANCIU, R. C. HOARE, AND J. R. BENNETT

Gastric emptying of barium sulphate suspension compared with that of water N. RAMSBOTTOM, M. T. KNOX, AND J. N. HUNT

Cholelithiasis in subjects with hypercalcaemia and primary hyperparathyroidism detected in a health screening T. CHRISTENSSON AND K. EINARSSON

Behaviour of ${ }^{125} \mathrm{I}$-fibrinogen and ${ }^{131} \mathrm{I}$-albumin in experimental galactosamine-induced hepatitis $\mathbf{I}$. MAHN, H. MERKEL, E. L. SATTLER, AND G. MÜLLERBERGHAUS
Functional renal failure and haemorrhagic gastritis associated with endotoxaemia in cirrhosis $\mathbf{C .}$ CLEMENTE, J. BOSCH, J. RHODÉS, V. ARROYO, A. MAS, AND S. MARAGALL

Hyperoxaluria correlates with fat malabsorption in patients with sprue G. B. MCDONALD, D. L. EARNEST, AND W. H. ADMIRAND

Effect of intraluminal oxygen on endotoxin absorption in experimental occlusion of the superior mesenteric artery $\mathrm{K}$. SHUTE

Variation in the incidence of diverticular disease within the city of Edinburgh M. A. EASTWOOD, JEAN SANDERSON, S. J. POCOCK, AND W. D. MTTCHELL

Double-blind placebo-controlled study of loperamide (Imodium) in chronic diarrhoea cuased by ileocolic disease or resection P. MAINGUET AND R. FIASSE

Progress report Cancer of the pancreas R. G. H. MORGAN AND K. G. WORMSLEY

Notes and activities

Books

Copies are still available and may be obtained from the PUBLISHING MANAGER, BRITISH MEDICAL ASSOCIATION, TAVISTOCK SQUARE, LONDON WC1H 9JR, price $£ 2 \cdot 75$, including postage 